\title{
Density and population structure of the natural regeneration of Scots pine (Pinus sylvestris L.) in the High Ebro Basin (Northern Spain)
}

\author{
Santiago C. González-Martínez ${ }^{\# * *}$ and Felipe Bravo \\ Departamento de Producción Vegetal y Silvopiscicultura, University of Valladolid at Palencia, \\ Avda. de Madrid, 57, 34004 Palencia, Spain
}

(Received 18 February 2000; accepted 21 August 2000)

\begin{abstract}
This paper presents the analysis of 11 natural regenerated stands in native Scots pine forests located in the High Ebro Basin (Northern Spain). The natural regeneration showed a continuous age distribution, early height differentiation and a high stability in the height position of seedlings. Total density and main crop (trees selected for future commercial harvest) density models were developed to study the relationship between natural regeneration and site variables. Soil sand content was an important ecological factor distinguishing two groups of plots. Hardwood and Ericaceae species competition were the main factors that explained total density but only in soils with low sand content. Intensive herbivore grazing was proposed to produce a strong reduction of viable seedlings. Thus, vegetation-control treatments and limitation of cattle grazing in regeneration areas are highly recommended in the native Scots pine forests of the High Ebro Basin.
\end{abstract}

natural regeneration / population structure / Pinus sylvestris / Mediterranean region / Spain

Résumé - Densité et structure des peuplements de Pin sylvestre (Pinus sylvestris L.) régénérés naturellement dans le HautBassin de l'Ebre (Nord de l'Espagne). Dans cet article sont analysés 11 peuplements régénérés naturellement, situés dans les forêts autochtones de Pin sylvestre du Haut-Bassin de l'Ebre (Nord de l'Espagne). La régénération naturelle a été caractérisée par une distribution continue de l'âge, une différenciation en hauteur précoce et une stabilité dans les classes de hauteur des plantules. Des modèles ont été développés pour étudier les relations entre la densité de la régénération naturelle et les variables du site. La densité totale et la densité moyenne de la récolte (la densité d'arbres sélectionnés qui constitueront la récolte commerciale future) ont été étudiées. Le contenu en sable du sol s'est révélé un facteur écologique important, permettant de distinguer deux groupes de sites. La compétition entre le résineux, les feuilleux et les espèces du genre Ericaceae a représenté le facteur principal qui expliquait la densité totale, mais seulement dans les sols peu sableux. Le pâturage intensif dû aux herbivores semble avoir produit une forte réduction des plantules viables. Par conséquent, les traitements pour contrôler la végétation adventice et la limitation du pâturage dans les zones de régénération sont très recommandés à l'intérieur des forêts autochtones de Pin sylvestre du Haut-Bassin de l'Ebre.

régénération naturelle / structure des peuplements / Pinus sylvestris / région Méditerranéenne / Espagne

\footnotetext{
* Correspondence and reprints

Tel. (34) 91347 6857; Fax. (34) 91357 2293; e-mail: santiago@inia.es

\# Present address: Department of Biotechnology and Breeding, Centre of Forest Research (CIFOR-INIA), P.O. Box 8111, 28080,

Madrid, Spain.
} 


\section{INTRODUCTION}

The demand for natural landscapes, the multi-resource use of forests and the high cost of plantations focus European foresters' attention on natural regeneration [1, $2,19,24]$. Works studying the population structure and the main factors affecting natural regeneration in Scots pine (Pinus sylvestris L.) are abundant in the literature. Most of them refer to boreal or Atlantic forests whereas studies in the Mediterranean or Atlantic-Mediterranean transition context are scarce. The climatic range is important because it influences the type and structure of soils, the composition of vegetal communities and the natural regeneration process. The climate affects the quantity and quality of seed crop [31] and determines the elongation of flower primordia [27], flowering phenology $[20,36]$ and pollen dispersal. The climatic factors are also important during germination and early development of seedlings. In Mediterranean forests, the summer length and climatic irregularity are the main causes of failure of natural regeneration, so that the combination of seed production and favourable climatic conditions for seedling establishment only occurs every 20-40 years $[28,33]$. Other main factors that affect regeneration success are herbivory and interspecific competition. Herbivore grazing reduces population density and height growth up to $30 \%$, and early growth losses are not made up with time [12]. Interspecific competition of vegetation groups like trees and shrubs [14], Ericaceae [17] and grasses [23] are reported to have different effects upon natural regeneration so they are studied independently in this paper.

The characteristics of natural regeneration of Scots pine in the southern limit of the distribution area for the species are poorly studied. Discussion of the important elements for natural regeneration density can be utilised to define the silviculture of Scots pine in Mediterranean areas where low-intensity forest management and in situ genetic resources conservation have increasing interest $[16,39]$. The aim of this work was: (1) the analysis of population structure of natural regeneration, (2) the study of density of Scots pine seedlings in relation to site variables and (3) the construction of predictive models for natural regeneration density.

\section{MATERIALS AND METHODS}

\subsection{Site description}

The Scots pine forests studied were situated at 710-910 masl in High Ebro Basin (Northern Spain) covering 13000 ha (figure 1). Silviculture in the area is based on natural regeneration following a shelterwood system and silvicultural interventions are not frequent at early stages of development. A site preparation consisting in a light soil scarification was in common practice in the area from the 1950s to the 1980s and so affected all the stands older than 10 years. The climate shows both Atlantic and Mediterranean influences, with an annual average rainfall of $787 \mathrm{~mm}$ (123 $\mathrm{mm}$ in summer) and an average annual temperature of $11.2{ }^{\circ} \mathrm{C}$, without pronounced droughts (figure 1). The high interannual variation of temperature and precipitation typical of Mediterranean climates is moderated by the Atlantic influence. The soils are calcareous cambisols evolving to luvisols in humid sites. The floristic community is composed of mixed Atlantic and Mediterranean elements. Quercus faginea Lamk. and Fagus sylvatica L. appear in soils with low sand content and some edaphic moisture, being substituted by Quercus ilex L. in xeric soils. In sites with a low pH, heather (Daboecia cantabrica (Hudson) C. Koch., Calluna vulgaris (L.) Hull., Erica vagans L. and Erica cinerea L.), gorse (Ulex europaeus L. and Ulex gallii L.) and fern (Pteridium aquilinum (L.) Kuch.) formations are frequent.

\subsection{Measurements}

The sample included 11 stands that represented the ecological variability of the study area (table I). A wide range of altitude (750-900 masl), slope (8-45\%) and overstorey basal area $\left(1.20-16.80 \mathrm{~m}^{2} \mathrm{ha}^{-1}\right)$, and different soil types (from cambisols to luvisols) were sampled. Sampling within the stands was conducted systematically based on a random start $(100 \times 100 \mathrm{~m}$ grid $)$. A total number of 80 plots were measured (table I). The plots were circular with a fixed radius of 2.5 meters $\left(19.6 \mathrm{~m}^{2}\right)$. Age and total height were measured on all Scots pine seedlings with diameter at breast height $(1.30 \mathrm{~m})$ less than $75 \mathrm{~mm}$. The age of the individuals was assessed by calculating the number of nodes. In some cases, there were not a clear differentiation of nodes and the seedlings were cut in order to estimate the age by ring counting. The seedlings were scored considering height position (dominant/codominant/intermediate/suppressed) and damage by grazing, stamping and pests (healthy/low damage/moderate damage/highly damaged). The term "main crop seedling", that is the trees selected to become a component of a future commercial harvest, referred to those seedlings with the highest score in both variables (dominant and healthy). The Stocked Quadrats method, with quadrats size of $4.9 \mathrm{~m}^{2}$, was used for stocking estimation. In this method, plots are divided in four quarters (the quadrats) and stocking is defined as the percentage of quadrats with at least one healthy and dominant seedling [26]. 


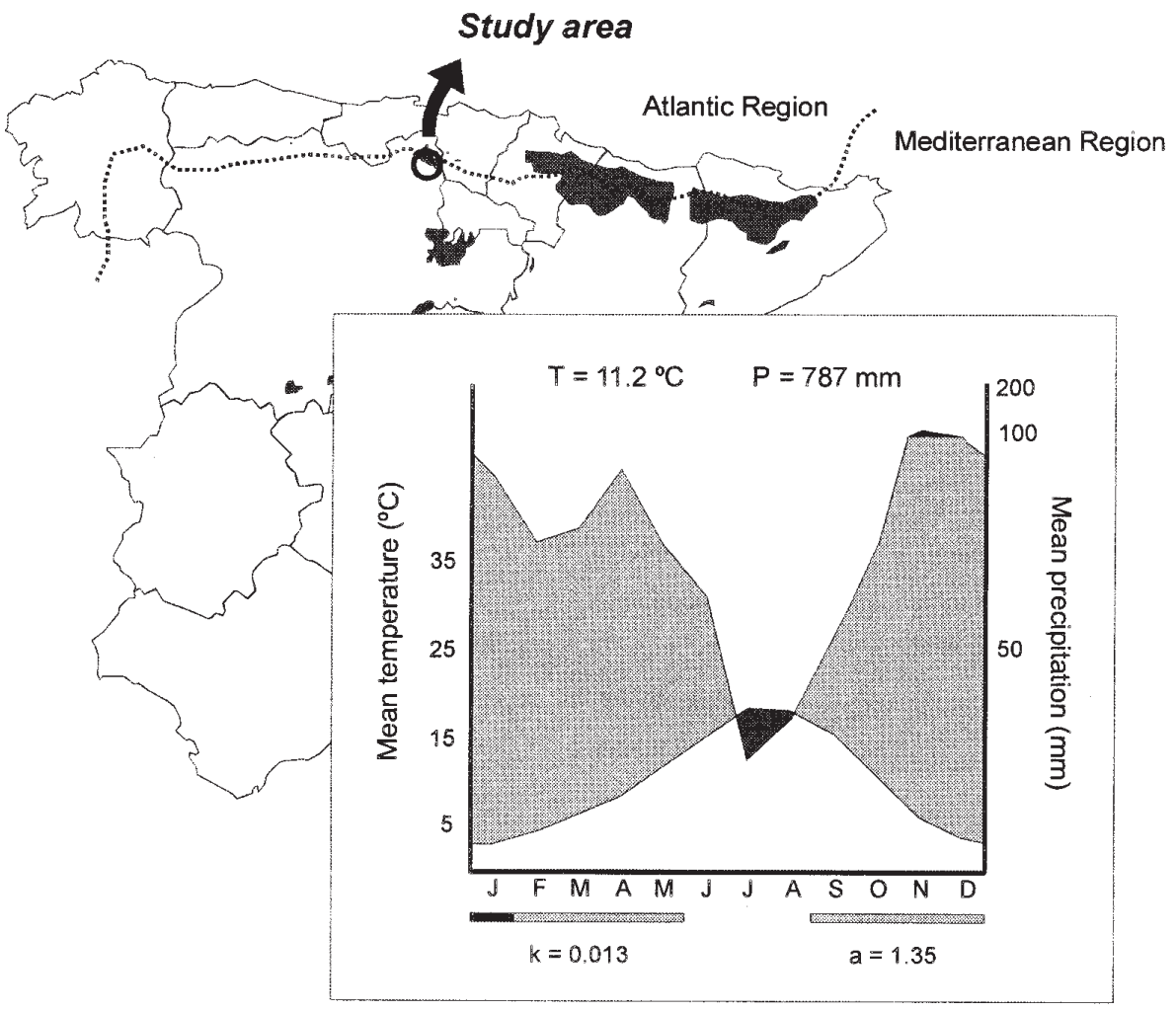

Figure 1. Walter-Lieth Climate Diagram and location map showing High Ebro Basin and its position related to the boundary between Atlantic and Mediterranean climates (dotted line) in Spain. The shadow area in the map indicates the native Northern Iberian distribution of Scots pine. Climate Diagram legend; dark shading: period of relative drought; light shading: period of relative humid season; T: annual average temperature; $\mathrm{P}$ : annual average rainfall; $\mathrm{k}$ : relative drought period/relative humid period ratio; a: period of relative drought in months.

Table I. Description of the stands.

\begin{tabular}{|c|c|c|c|c|c|c|}
\hline $\begin{array}{c}\text { Stand } \\
\text { number }\end{array}$ & $\begin{array}{l}\text { Area } \\
\text { (ha) }\end{array}$ & $\begin{array}{l}\text { Number } \\
\text { of plots }\end{array}$ & $\begin{array}{l}\text { Overstorey basal } \\
\text { area }\left(\mathrm{m}^{2} \mathrm{ha}^{-1}\right)\end{array}$ & $\begin{array}{l}\text { Altitude } \\
\text { (masl) }\end{array}$ & $\begin{array}{l}\text { Slope } \\
(\%)\end{array}$ & Aspect \\
\hline 1 & 4.30 & 5 & 4.30 & 800 & 8 & S-W-N \\
\hline 2 & 7.25 & 8 & 11.30 & 885 & 8 & W \\
\hline 3 & 5.90 & 6 & 3.40 & 750 & 21 & N-E \\
\hline 4 & 5.20 & 5 & 6.12 & 760 & 33 & N-E \\
\hline 5 & 11.42 & 12 & 3.05 & 840 & 9 & S-W-N-E \\
\hline 6 & 4.25 & 5 & 1.20 & 850 & 36 & $\mathrm{~N}$ \\
\hline 7 & 8.59 & 9 & 1.79 & 760 & 11 & W-N-E \\
\hline 8 & 5.03 & 5 & 3.00 & 800 & 45 & S-W \\
\hline 9 & 6.07 & 6 & 1.58 & 810 & 15 & $\mathrm{~N}$ \\
\hline 10 & 8.72 & 9 & 1.70 & 900 & 24 & S-W-N-E \\
\hline 11 & 10.11 & 10 & 16.80 & 875 & 16 & S-E \\
\hline
\end{tabular}

The site variables measured were classified into physiographic data (altitude, slope and aspect), edaphic data (texture and thickness of the humus layer), vegetation data (cover and mean height of different vegetation groups), and forest management data (residual basal area, distance from the nearest seed source and soil preparation). The description of site variables is shown in table II. Soil was evaluated following a field categori- cal method based on moistened samples collected at $20 \mathrm{~cm}$ depth [30]. Four sand content categories were differentiated: below $40 \%$, between 40 and $65 \%$, between 65 and $80 \%$ and higher than $80 \%$. Some samples $(18.75 \%)$ were also analysed in the laboratory in order to check the accuracy of field estimations. Cover of the different groups of plants was visually scored using schematic diagrams illustrating covers from 0 to $100 \%$ 
Table II. Description of the site variables included in the regression models.

\begin{tabular}{|c|c|c|c|c|}
\hline Variable & Type & Range & Classes & Description \\
\hline \multicolumn{5}{|c|}{ Physiographic data } \\
\hline ALT & Quantitative & $700-900$ & - & Altitude above sea level (m). \\
\hline SLO & $\%$ & 0-90 & - & Slope measured with a clisimeter located in the middle of the plot. \\
\hline ASP & Binary & - & aspl & Exposition of the plot, a binary variable that indicates Northern exposition. \\
\hline \multicolumn{5}{|c|}{ Edaphic data } \\
\hline \multirow[t]{3}{*}{ TEXT } & Categorical & - & text1 & $\begin{array}{l}\text { Sand content of the soil following a field categorical method. Dummy variable for sand } \\
\text { content higher than } 80 \% \text {. }\end{array}$ \\
\hline & & - & text 2 & $\begin{array}{l}\text { Sand content of the soil following a field categorical method. Dummy variable for sand } \\
\text { content between } 65 \% \text { and } 80 \% \text {. }\end{array}$ \\
\hline & & - & text 3 & $\begin{array}{l}\text { Sand content of the soil following a field categorical method. Dummy variable for sand } \\
\text { content between } 40 \% \text { and } 65 \% \text {. }\end{array}$ \\
\hline THIC & Quantitative & $0-9$ & - & Thickness of the humus layer $(\mathrm{cm})$ \\
\hline \multicolumn{5}{|c|}{ Vegetation data. } \\
\hline PC 1 & Quantitative & - & - & (1) Principal Component 1 . Related to cover and mean height of hardwood species. \\
\hline PC 2 & Quantitative & - & - & (1) Principal Component 2. Related to cover and mean height of Ericaceae plants. \\
\hline PC 3 & Quantitative & - & - & (1) Principal Component 3. Related to cover of grasses. \\
\hline \multicolumn{5}{|c|}{ Forest management data } \\
\hline BAS & Quantitative & $0-31$ & - & Overstorey basal area $\left(\mathrm{m}^{2} \mathrm{ha}^{-1}\right)$. \\
\hline DIST & Quantitative & $1-80$ & - & Distance from the seed source $(\mathrm{m})$. \\
\hline PREP & Binary & - & prepl & Site preparation, a binary variable that indicates when site preparation has been made. \\
\hline TIME & Quantitative & $0-23$ & - & Time from the beginning of the regeneration process in each stand (years). \\
\hline
\end{tabular}

(1) See further explanation in the text.

(5\% step) under different spatial patterns. Mean height of the different groups was measured as follows: for each group of species the plot was divided into portions each having roughly constant height, separate mean heights were obtained for each portion by measuring a sample of at least 10 individuals (when available), and the values were combined in a weighted mean [13]. The variable Time, defined as the number of years from the beginning of the regeneration process (known by management records), was used in order to know if density increased, decreased, or remained constant during the regeneration period.

\subsection{Data analysis}

The data analysis was conducted in two steps. The first step was the analysis of population structure of natural regeneration. Then, the selection and interpretation of the main factors that affected density and the construction of predictive models were made.

The population structure of each stand was analysed by means of total density, main crop density and stocking calculations. Pattern, height and age structure analysis were also performed. Pattern analysis was based on
Blackman's coefficient [13]. This test makes use of the equality of mean and variance of the Poisson distribution. If the ratio of variance to mean is less than one, a regular pattern is indicated, if greater than one, a clumped pattern. Deviations from a random spatial pattern were tested using the Student t-test. Height and age structure analysis was carried out comparing the mean height of seedlings belonging to consecutive age-classes. Student t-tests comparing consecutive age-classes were done for each stand following Schepper [37]. Only ageclasses with more than five trees were included. In addition, box-and-whisker plots for total height and age distributions were plotted. The whole set of data (80 plots) was used is this first step.

Explanatory interpretation of factors affecting density of natural regeneration was made by multiple regression analysis, adjusting models between total density and main crop density, and the site variables in table II. Because vegetation variables were strongly correlated (Pearson's correlation coefficient higher than 0.75 in some cases), principal component analysis (PCA) was used to get a set of independent variables from these data. The number of factors retained in the PCA was determined using the factors/eigenvalues plot [15]. Three principal components, explaining a $69.24 \%$ of the total 
variance, were included in the models. Principal Component 1 (PC 1) had a high correlation with cover (0.93) and mean height (0.91) of the hardwood species present in the study area (mainly Quercus faginea, Quercus ilex and Fagus sylvatica), Principal Component 2 (PC 2) was strongly correlated with the cover (0.88) and mean height (0.86) of plants of the Ericaceae group (Daboecia cantabrica, Erica cinerea, Erica vagans and Calluna vulgaris) and Principal Component 3 (PC 3) was correlated with the cover (0.95) of grasses present in each plot (mainly Brachypodium phoenicoides (L.) Roemer and Schultes, Dactylis glomerata L., Holcus lanatus L. and Arrhenatherum elatius (L.) Beauv.). Categorical variables with $k$ classes were included in the models defining $(k-1)$ dummy variables. Starting from the saturated model where the effect of continuos variables is allowed to vary across all categories, the significance of interactions was tested by gradually simplifying the model. Only the dummy variable textl (soil sand content higher than $80 \%$ ) had a significant interaction both in the total density and main crop density models, thus suggesting different performance of the quantitative variables for plots with different sand content. There were not enough plots, only eight, in sites with high sand content to adjust any model, so they were dropped for further analysis. Once the plots that caused the interaction effect were dropped, the following linear model was constructed:

$$
y=\beta_{0}+\beta_{1} x_{1}+\beta_{2} x_{2}+\ldots+\beta_{n} x_{n}+\varepsilon
$$

where $y$ was the total density or main crop density depending on the model; $x_{1}, x_{2}, \ldots x_{n}$ were the site variables; $\beta_{0}, \beta_{1}, \beta_{2}, \ldots \beta_{n}$ were the parameters to estimate; and $\varepsilon$ was the experimental error. Linear models were estimated by weighted least-squares regression. This method does not alter the model structure and produces a near-constant variance of the residuals. The weighting factor was the inverse of the variance. Two thirds of the data (47 plots, after removing sandy plots) were used for the final model construction and one-third for its validation (25 plots).

The normality, linear independence and homogeneity of variance of the residuals were studied using the Shapiro-Wilk test, the normal probability plot and the residual values/predicted values plot. The variables were transformed, $x=(x+0.5)^{0.5}$, to approach normality. This transformation is normally used with data that include many zero values $[13,38]$. Percentage data were normalised using the logit transformation: $z=\log \{p /(1-$ $p)\}$. The logit transformation modifies a variable having a range 0 to 1 to a variable with no restrictions, similar to one that is normally distributed. Zero values were replaced with $25 / n$ and 100 -percent values with 100 -
$(25 / n)$, where $n$ was the sample size [4]. The atypical and influential points were detected by analysing the Studentized residuals and Cook's $D$, Dfbeta and Covratio values which measure the effect of an individual observation on the dependent variable, the regression coefficients and the variance-covariance matrix of the parameter estimates, respectively [32]. Validation of the models was done by studying the distribution, mean and variance of residuals of 25 plots not used in model construction. SAS ${ }^{\circledR}$ version 6.0 program was used for statistical analysis.

\section{RESULTS}

\subsection{Population structure of natural regeneration}

The mean total density was $0.51 \pm 0.15$ seedlings $\mathrm{m}^{-2}$, with a minimum and maximum values of 0.13 and 0.93 seedlings $\mathrm{m}^{-2}$, respectively (table III). Main crop density accounted for $46 \%$ of the total density. The stocking ranged from $18 \%$ in Stand 2 to $78 \%$ in Stand 7. Only $20 \%$ of plots had full stocking but $45 \%$ of plots were above $50 \%$ of stocking. The spatial pattern was clumped in all sites except in Stand 1, which showed a regular distribution.

The natural regeneration showed a nearly continuous age distribution (figure 2). There was a large difference between minimum and maximum individual tree age in each stand, with an uppermost range of 19 years (Stand 8) and 20 years (Stand 7). Although the upper stratum generally corresponded to the oldest seedlings, some new individuals had established during late stages of the regeneration phase. For instance, differences of 10 years between dominant trees could be found in Stand 9 (figure 3). However, there was a notable difference in mean height between consecutive age-classes (19 from 37 t-tests with $p<0.05$ ) indicating a marked stability of the height position of seedlings. Within each age, the difference between the upper and the lower quartile for total height increased with age. In a particular and extreme case it was found a difference of $2 \mathrm{~m}$ in two seedlings that were both 13 years old (Stand 6).

\subsection{Main factors affecting density of seedlings}

The saturated models showed an interaction between soils with sand content higher than $80 \%$ (text 1$)$ and the other variables included in the models (table IV; only variables included in the final predictive models are shown). This result suggested a different pattern in soils with sand content above and below $80 \%$. Field observations showed that the site preparation and the 
Table III. Main characteristics and population structure parameters of natural regeneration in the study area.

\begin{tabular}{|c|c|c|c|c|c|c|c|c|c|c|}
\hline \multirow[t]{2}{*}{ Stand } & \multirow{2}{*}{$\begin{array}{c}\text { Density } \\
{\text { (seedlings } \mathrm{m}^{-2} \text { ) }}^{\text {s. }}\end{array}$} & \multirow{2}{*}{$\begin{array}{l}\text { Main crop } \\
\text { density }\end{array}$} & \multirow{2}{*}{$\begin{array}{l}\text { Mean age } \\
\text { (years) }\end{array}$} & \multirow{2}{*}{$\begin{array}{l}\mathrm{H}_{\mathrm{m}} \\
(\mathrm{m})\end{array}$} & \multicolumn{5}{|c|}{ Stocking (\%) } & \multirow[t]{2}{*}{ Pattern } \\
\hline & & & & & 0 & 25 & 50 & 75 & 100 & \\
\hline 1 & $0.23 \pm 0.12$ & $0.12 \pm 0.07$ & $13.20 \pm 2.09$ & $1.94 \pm 0.76$ & 0 & 1 & 2 & 0 & 2 & $0.69^{\mathrm{ns}}$ \\
\hline 2 & $0.13 \pm 0.18$ & $0.10 \pm 0.13$ & $1.43 \pm 1.65$ & $0.05 \pm 0.05$ & 4 & 2 & 2 & 0 & 0 & $1.84 * *$ \\
\hline 3 & $0.28 \pm 0.10$ & $0.13 \pm 0.56$ & $8.00 \pm 3.24$ & $1.21 \pm 0.50$ & 1 & 1 & 0 & 3 & 1 & $2.06 * *$ \\
\hline 4 & $0.59 \pm 0.92$ & $0.52 \pm 0.89$ & $4.50 \pm 3.25$ & $0.24 \pm 0.16$ & 1 & 1 & 2 & 0 & 1 & $2.63 * *$ \\
\hline 5 & $0.50 \pm 0.29$ & $0.45 \pm 0.29$ & $1.44 \pm 0.47$ & $0.12 \pm 0.03$ & 2 & 0 & 3 & 3 & 4 & $4.31 * * *$ \\
\hline 6 & $0.41 \pm 0.16$ & $0.14 \pm 0.12$ & $10.40 \pm 1.71$ & $1.64 \pm 0.49$ & 0 & 0 & 2 & 3 & 0 & $2.76 * * *$ \\
\hline 7 & $0.69 \pm 0.32$ & $0.10 \pm 0.10$ & $12.07 \pm 2.08$ & $0.84 \pm 0.29$ & 0 & 0 & 3 & 2 & 4 & $4.44 * * *$ \\
\hline 8 & $0.33 \pm 0.15$ & $0.10 \pm 0.10$ & $10.00 \pm 5.29$ & $1.14 \pm 0.64$ & 1 & 0 & 2 & 2 & 0 & $6.27 * * *$ \\
\hline 9 & $0.23 \pm 0.03$ & $0.09 \pm 0.04$ & $18.50 \pm 2.81$ & $2.26 \pm 0.53$ & 0 & 1 & 2 & 3 & 0 & $1.74 *$ \\
\hline 10 & $0.93 \pm 0.86$ & $0.40 \pm 0.45$ & $3.83 \pm 2.30$ & $0.29 \pm 0.21$ & 3 & 0 & 1 & 3 & 2 & $7.03 * * *$ \\
\hline 11 & $0.82 \pm 0.62$ & $0.38 \pm 0.31$ & $3.60 \pm 1.66$ & $0.25 \pm 0.14$ & 3 & 1 & 2 & 1 & 3 & $10.49 * * *$ \\
\hline
\end{tabular}

$\mathrm{H}_{\mathrm{m}}$ : Mean height; Stocking: Number of plots with 0, 25, 50, 75 and 100\% stocking. Pattern: Blackman's coefficient and test of deviation from random distribution.

Table IV. Saturated models showing interaction effects between the dummy variable text1 (soils with sand content higher than $80 \%$ ) and the variables included in the final predictive models for total density and main crop density.

\begin{tabular}{|c|c|c|c|c|c|}
\hline Model $\left(A d j-r^{2}\right)$ & Variable & d.f. & Parameter estimate & Standard error & $t$ \\
\hline $\begin{array}{l}\text { TOTAL DENSITY } \\
(0.3988)\end{array}$ & $\begin{array}{c}\text { CONSTANT } \\
\text { TIME } \\
\text { PC } 1 \\
\text { PC } 2 \\
\text { Text1 } \\
\text { Text } 1 * \text { TIME } \\
\text { Text } 1 * \text { PC } 1 \\
\text { Text } 1 * \text { PC } 2\end{array}$ & $\begin{array}{l}1 \\
1 \\
1 \\
1 \\
1 \\
1 \\
1 \\
1\end{array}$ & $\begin{array}{r}10.714 \\
2.075 \\
-11.496 \\
-5.652 \\
222.066 \\
-16.589 \\
21.596 \\
30.224\end{array}$ & $\begin{array}{r}2.129 \\
0.846 \\
5.503 \\
5.432 \\
62.094 \\
7.991 \\
14.909 \\
44.077\end{array}$ & $\begin{array}{l}0.0388 \\
0.0181 \\
0.0424 \\
0.3037 \\
0.0008 \\
0.0437 \\
0.1544 \\
0.4964\end{array}$ \\
\hline $\begin{array}{l}\text { MAIN CROP DENSITY } \\
(0.4940)\end{array}$ & $\begin{array}{c}\text { CONSTANT } \\
\text { Prep1 } \\
\text { PC } 1 \\
\text { PC } 3 \\
\text { Text1 } \\
\text { Text } 1 * \text { Prep1 } 1 \\
\text { Text } 1 * \text { PC } 1 \\
\text { Text } 1 * \text { PC } 3\end{array}$ & $\begin{array}{l}1 \\
1 \\
1 \\
1 \\
1 \\
1 \\
1 \\
1\end{array}$ & $\begin{array}{r}10.226 \\
27.576 \\
-5.980 \\
-10.602 \\
74.384 \\
-36.834 \\
18.648 \\
13.327\end{array}$ & $\begin{array}{r}6.452 \\
8.380 \\
4.983 \\
6.236 \\
19.194 \\
35.294 \\
9.452 \\
22.279\end{array}$ & $\begin{array}{l}0.1203 \\
0.0020 \\
0.2367 \\
0.0963 \\
0.0004 \\
0.3025 \\
0.0550 \\
0.5528\end{array}$ \\
\hline
\end{tabular}

interspecific competition (both important in the plots with sand content below $80 \%$ ) were apparently not affecting natural regeneration density in plots with high sand content. However, there were not enough plots in sites with sand content higher than $80 \%$ (only eight) to undertake the modelling of this group and, therefore, no conclusive results could be obtained. These plots were removed from the data set to allow the estimation of main effects in the final predictive models that are only valid for plots with sand content below $80 \%$ (table $\mathrm{V}$ ).
The total density model, which accounted for $54 \%$ of the variation, included overstorey and understorey vegetation cover and mean height (PC1 and PC2, respectively) and the time from the beginning of the regeneration process. Total density of natural regeneration was positively correlated with the time from the beginning of the regeneration phase and negatively correlated with cover and mean height of hardwood and Ericaceae species. The magnitude of the correlation between each group of species and total density was similar, as shown by the parameter estimates. With respect to the main crop 
STAND 1

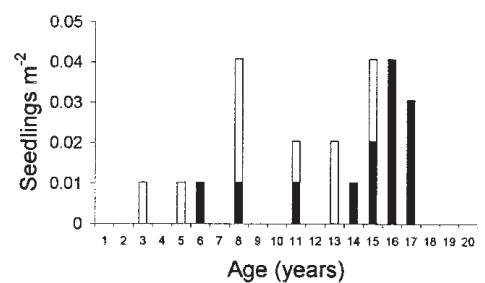

STAND 4

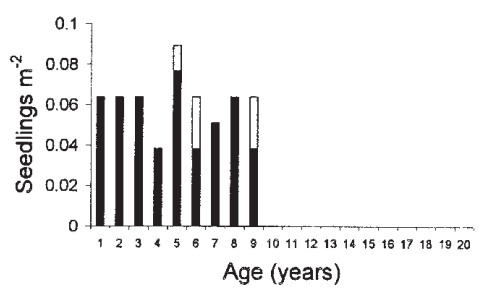

STAND 7

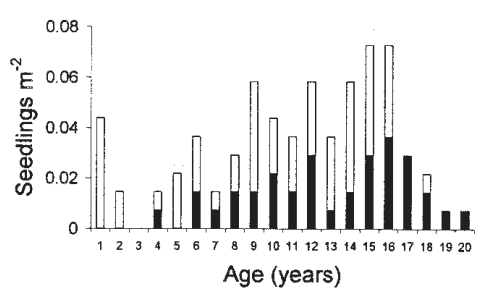

STAND 2

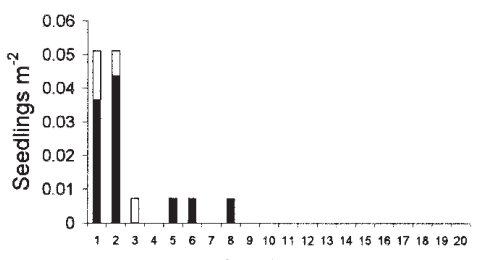

Age (years)

STAND 5

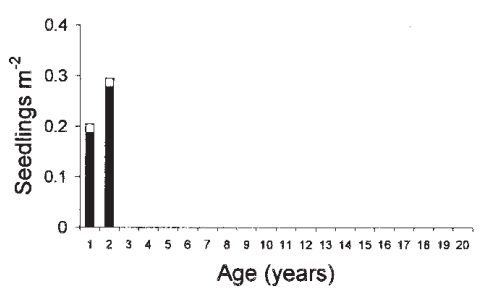

STAND 8

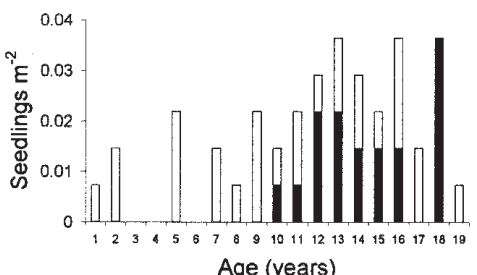

STAND 3

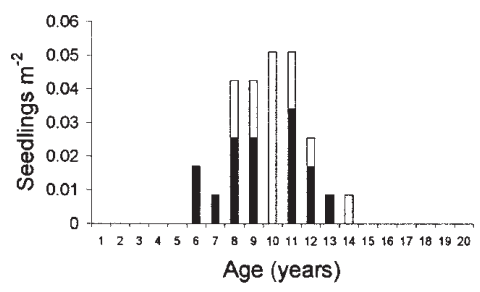

STAND 6

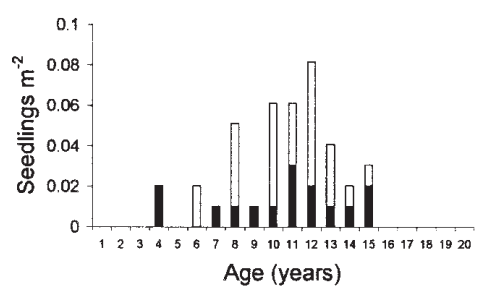

STAND 9

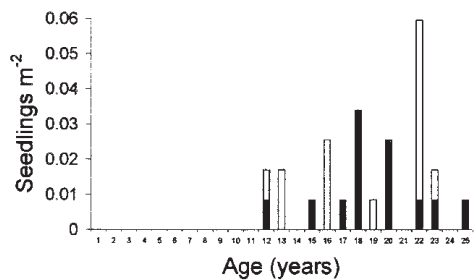

STAND 10

STAND 11
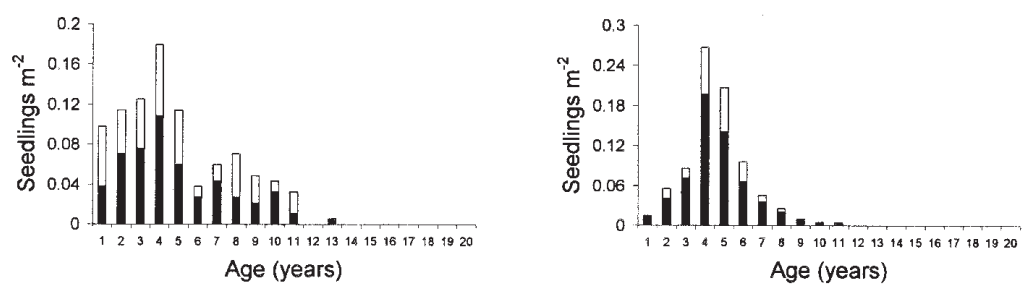

Figure 2. Age structure of 11 natural regenerated stands in the High Ebro Basin (Northern Spain). White bars indicate suppressed or injured seedlings.

density, the model showed a positive correlation between the establishment of successful seedlings and site preparation. In fact, holding constant the other factors (equal to the average in the study area), the model predicts an increase in the number of main crop seedlings from 0.03 to 1.30 seedlings $\mathrm{m}^{-2}$ when site preparation is made. On the contrary, grasses cover (PC 3 ) and cover and mean height of hardwood species (PC 1) were negatively correlated with the density of main crop seedlings.
The residual analysis of the final predictive models showed no violations of the assumptions (figure 4). Because atypical values were representative of the high ecological variability of the sampled area, they were not removed from the models. With respect to the validation analysis, the residuals showed a normal distribution both in the total density (Shapiro-Wilk's test $=0.98$ ) and main crop density (Shapiro-Wilk's test $=0.93$ ) models. The means of the residuals were 0.69 and 0.78 in the total 

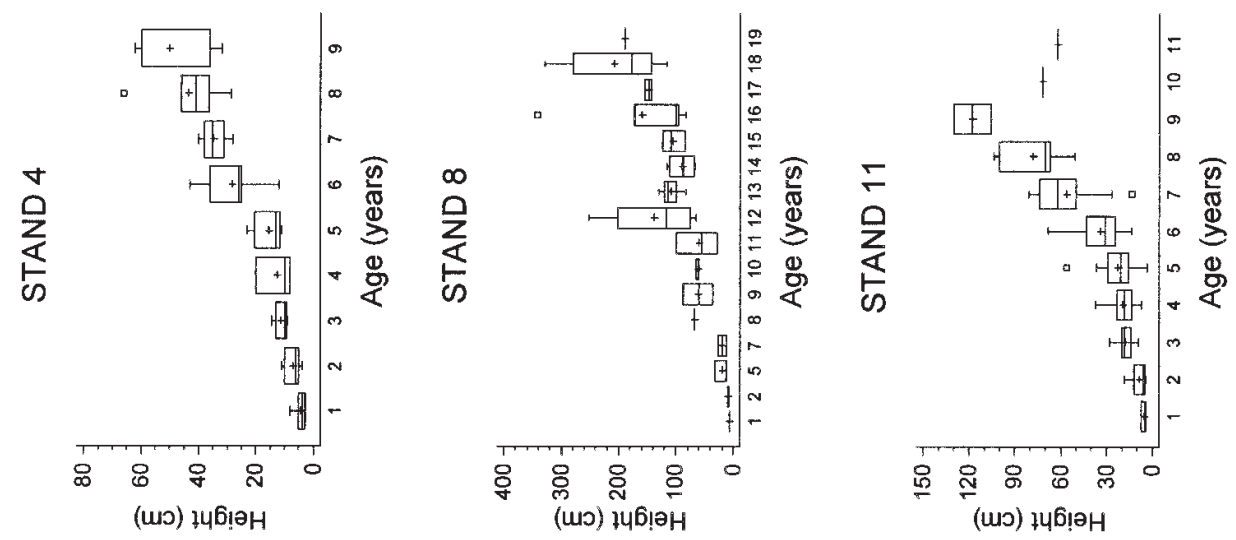

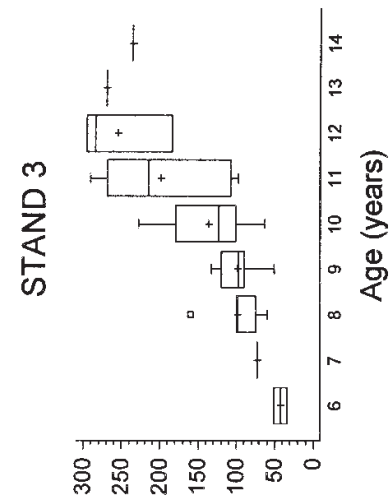

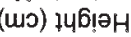

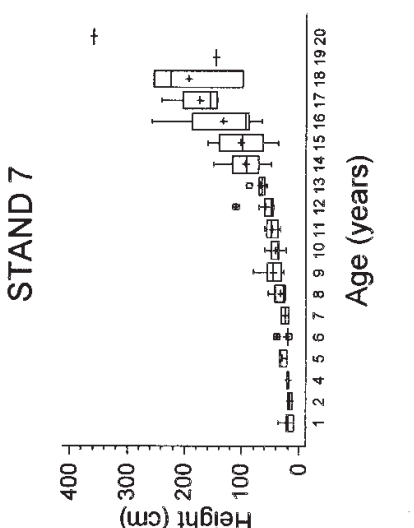

(uv) +46 ํㅣㄱ
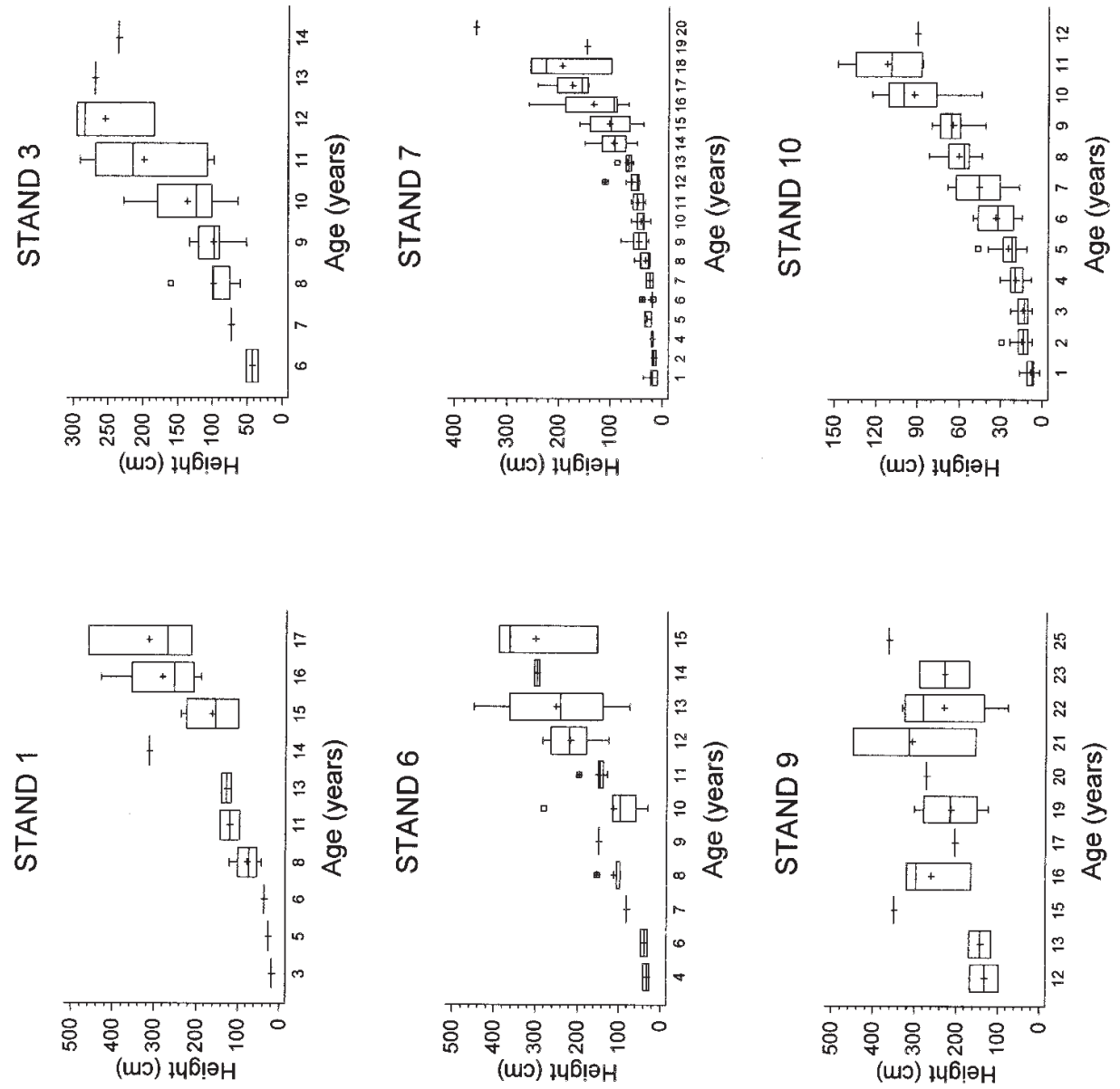
Table V. Weighted linear regression models for total density and main crop density.

\begin{tabular}{lccccc}
\hline Model $\left(\right.$ Adj- $\left.r^{2}\right)$ & Variable & d.f. & Parameter estimate & Standard error & $t$ \\
\hline TOTAL DENSITY & CONSTANT & 1 & 14.012 & 8.154 & 0.0931 \\
$(0.5378)$ & TIME & 1 & 2.738 & 0.699 & 0.0003 \\
& PC 1 & 1 & -11.831 & 2.120 & 0.0001 \\
& PC 2 & 1 & -9.512 & 4.408 & 0.0367 \\
MAIN CROP DENSITY & CONSTANT & 1 & 11.534 & 2.948 & 0.0003 \\
$(0.5087)$ & Prep 1 & 1 & 20.912 & 4.284 & 0.0001 \\
& PC 1 & 1 & -5.136 & 1.475 & 0.0012 \\
& PC 3 & 1 & -8.877 & 2.164 & 0.0002 \\
\hline
\end{tabular}

density and main crop density models, respectively, and not differed significantly from zero as shown by Student t-tests. In addition, the variances of the residuals were not different than the mean square errors of the models.

\section{DISCUSSION}

\subsection{Population structure of natural regeneration}

Multicohort stand dynamics were outlined by Oliver and Larson [29] for the single-species case, suggesting that the loss of vitality and death of shrubs and grasses due to the effect of minor disturbances allowed the establishment of new seedlings and produced nearly continuous age distributions. Complex stand structures and continuos age distributions due to episodic partial disturbances have been also found in mixed-species stands [9]. In contrast, in cases of severe disturbances, like a fire, the occupation of all the growing space in the first twothree years and the non viability of later settlers have been reported. For instance, Lust [25] indicated a regeneration period of only four years after a fire in a 600 ha Scots pine forest (High Campine, Belgium). A similar process to that described by Oliver and Larson [29] enhanced by the climatic irregularity of the area could produce the natural regeneration structure observed in the High Ebro Basin. A continuous series of climatic data (1951-1992; National Meteorological Agency, "Duero" Regional Centre) showed variation in climatic types from dry Mediterranean (during 7 years) to typical Atlantic (during 16 years) and a great variety of transitional types. Annual weather fluctuations have been reported as minor disturbances that are of great importance in the first stages of stand development [29]. The establishment of new seedlings in the stands may be caused by the loss of vitality and death of shrubs, grasses and other tree seedlings due to the effect of drought in dry years. The variation in height growth of Scots pine

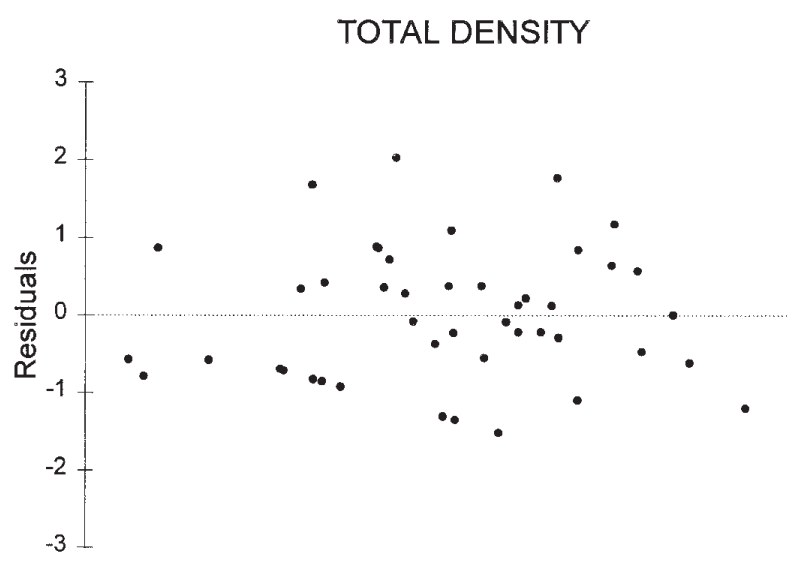

MAIN CROP DENSITY

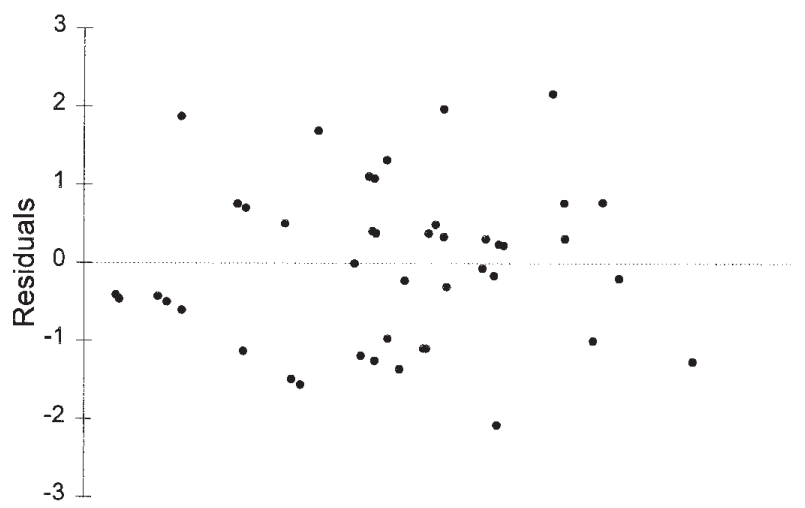

Figure 4. Residual values versus predicted values plot for total density and main crop density models.

seedlings has been suggested to be caused mostly by the spatial heterogeneity of the stand [21]. Differences in microsite variables affecting height growth could explain the possibility of promotion of later settlers to the 
dominant stratum. Limited recruitment of tree seedlings due to low seed production or seed predation could also explain the observed population structure. Seed predation has important effects in the availability of seeds of Pinus species, being a key factor in small size populations [22]. As much as a $90 \%$ of pre-dispersal predation and a $61-96 \%$ of post-dispersal predation has been reported in relict stands of Pinus sylvestris in southeastern Spain [6]. However, seed availability does not seem a limiting factor in the High Ebro Basin where seed production is usually high and seed predation is reduced by the existence of other major food sources (e.g. Fagus sylvatica, Quercus spp).

The difference of height between consecutive ageclasses indicates a high stability of the seedlings height positions. Ruha et al. [34] showed that the height positions are primarily established during the first 5-10 years at a mean height of less than $0.5-1 \mathrm{~m}$ and might be determined even by the height growth of the very first year. Early differentiation favours the natural selection of seedlings increasing the total yield at harvest time [14]. In the study area, the stability of the height positions is favoured by the heterogeneous pattern and the low-medium density of trees. In contrast, in high density stands of 6 to 15-year-old Scots pine, Ganther [11] observed trees moving from one height class to another. The early height differentiation and the stability of height positions allow an early selection of trees in the study area. In precommercial thinning, the height position of a tree could be used as an important criterion in the selection of the remaining trees.

\subsection{Main factors affecting density of seedlings}

Limited recruitment of seedlings in forest species due to interspecific competition is well-stated in the literature. The climatic conditions of the study area are suitable for the establishment of hardwood species (mainly $Q$. faginea and $F$. sylvatica). Schepper [37] showed constant growing rates for Scots pine in comparison with exponential growing rates for initial stages of oak species. This causes a clear initial competitive disadvantage for pine regeneration and poorly stocked stands as in the study area. The competition from broad-leaved species also seems to be the main limiting factor for Scots pine recruitment in Northern Italy [5]. The models assign a relevant role to the presence of Ericaceae in the natural regeneration success. Inhibition of germination of red clover by phenolic compounds from the aerial parts and roots of Erica vagans, Calluna vulgaris and Daboecia cantabrica has been reported in laboratory assays [3]. Other plants with potential allelopathic effects on Scots pine regeneration - like Vaccinium myr- tillus or Pteridium aquilinum - are not likely to be of importance in the area because they have inhibitory compounds which are relatively more soluble than those from Ericaceae species [17] or their stocking is low in the study area. Lust [25], studying natural regeneration after a fire, pointed out the importance of physiographic factors (aspect, slope). In our study, physiographic factors were not significant probably due to a greater importance of interspecific competition and the absence of large disturbances [29, 40]. On the other hand, Scandinavian authors reported the importance of neighbouring seed-producing stands for regeneration success $[2,35,41]$. The extreme temperatures of Northern Europe limit Scots pine's flowering and cone production [18], whereas in High Ebro Basin seed production is usually abundant.

The grass layer is a physical barrier preventing fallen seeds from contacting the mineral soil. It also means a strong competition with settled seedlings. For instance, a $16 \%$ of height growth reduction has been observed in Pinus taeda with grass seeding of Festuca arundinacea applied at a rate of $2.8 \mathrm{~g} \mathrm{~m}^{-2}$ [10]. Competition intensity with herbaceous vegetation is likely to increase in environments with low water availability [7]. In the study area, tree seedling success may be strongly influenced by competition for water during dry years. In addition, livestock and herbaceous plants are in close interrelation. Continuous cattle grazing changes the floristic community producing a dense pasture enriched with palatable species where cattle tend to concentrate. A strong reduction of main crop seedlings due to herbivores grazing and stamping in forest regeneration areas is common in the High Ebro Basin. In these cases, injured plants are frequent and the density of main crop seedlings is reduced. Cattle pressure produces reductions of growth, vigour and quality of wood in the Scots pine seedlings. Gong et al. [12] reported that in native pinewoods at Glen Tanar, Aberdeenshire (Scotland), the dominant seedlings, defined as the tallest 10 percent of seedlings in each plot, when aged 12 (61.5 cm height) were $22 \mathrm{~cm}$ higher in fenced than in unfenced plots. Slow-growing Scots pine plants are less able to compensate for biomass losses and, therefore, they have less chances to survive when attacked [8]. In consequence, damage is more detrimental in poor sites, thus increasing regeneration difficulties. Fencing seems to be, in the long term, the only reliable way of securing the development of natural regeneration in these areas.

Acknowledgements: The authors wish to thank A. Picardo for valuable discussions and encouragement; R. Alía, D. Agúndez, G. Montero, S. Mutke and E. Castro for comments on the manuscript and F. Merino, C. Gil, I. López and M.E. Abril for generous field assistance. The 
comments of two anonymous referees were greatly appreciated. Finally, thanks to P.C. Grant, J. Pajares and J. Hamann who checked the English, and to M. Ribeiro and S. Mariette who made the French abstract.

\section{REFERENCES}

[1] Ackzell L., A comparison of planting, sowing and natural regeneration for Pinus sylvestris (L.) in boreal Sweden, For. Ecol. Manage. 61 (1993) 229-245.

[2] Ackzell L., Natural regeneration on planted Clear-Cuts in Boreal Sweden, Scand. J. For. Res. 9 (1994) 245-250.

[3] Ballester A., Vieitez A.M., Vieitez E., Allelopathic potential of Erica vagans, Calluna vulgaris and Daboecia cantabrica, J. Chem. Ecol. 8 (1982) 851-857.

[4] Bartlett M.S., The use of transformations, Biometrics 3 (1947) 39-52.

[5] Bucci G., Borghetti M., Understorey vegetation as a useful predictor of natural regeneration and canopy dynamics in Pinus sylvestris forests in Italy, Acta Oecologica 18 (1997) 485-501.

[6] Castro J., Gómez J.M., García D., Zamora R., Hódar J.A., Seed predation and dispersal in relict Scots pine forests in Southern Spain, Plant Ecol. 145 (1999) 115-123.

[7] Davis M.A., Wrage K.J., Reich P.B., Competition between tree seedlings and herbaceous vegetation: support for a theory of resource supply and demand, J. Ecol. 86 (1998) 652-661.

[8] Edenius L., Danell K., Nyquist A., Effects of simulated moose browsing on growth, mortality, and fecundity in Scots pine: relations to plant productivity, Can. J. For. Res. 25 (1995) 529-535.

[9] Fajvan M.A., Seymour R.S., Canopy stratification, age structure, and development of multicohort stands of eastern white pine, Eastern hemlock, and red spruce, Can. J. For. Res. 23 (1993) 1799-1809.

[10] Fredericksen T.S., Zedaker S.M., Smith D.V., Seiler J.R., Kreh R.E., Early stand dynamics in a field competition experiment with loblolly pine, red maple, and black locust, in: Sixth biennial Southern silvicultural research conference, Memphis, 1990, pp. 630-640.

[11] Ganther S., Untersuchung über die Wuchsdynamik, Nachbarschaft, soziologische Umsetzung und Qualitätsentwicklung in natürlich verjüngten FöhrenJungwäldern in der Gemeinde Glattfelden, Schweiz. Z. Forstwes. 134 (1983) 905-914.

[12] Gong Y.L., Swaine M.D., Miller H.G., Effects of fencing and ground preparation on natural regeneration of native pinewood over 12 years in Glen Tanar, Aberdeenshire, Forestry 64 (1992) 157-168.

[13] Greig-Smith P., Quantitative Plant Ecology, Butterworths, London, 1983.

[14] Hari P., Kellomäki S., Mäkelä A., Ilonen P., Kanninen M., Korpilahti E., Nygrén M., Metsikön varhaiskehityksen dynamiikka, Acta For. Fenn. 177 (1991) 1-42.
[15] Hatcher L., A step-by-step approach to using the SAS ${ }^{\circledR}$ system for factor analysis on structural equation modelling, SAS Institute Inc., Cary, 1994.

[16] Hattemer H.H., Concepts and requirements in the conservation of forest genetic resources, Forest Genetics 2 (1995) $125-134$.

[17] Jäderlund A., Zackrisson O., Nilssön M.C., Effects of bilberry (Vaccinium myrtillus L.) litter on seed germination and early seedling growth of four boreal tree species, J. Chem. Ecol. 22 (1996) 973-986.

[18] Kellomäki S., Väisänen H., Model computations on the impact of changing climate on natural regeneration of Scots pine in Finland, Can. J. For. Res. 25 (1995) 929-942.

[19] Kinnunen K., Combination on Natural and Artificial Seeding in Regeneration of Scots Pine, Invest. Agrar. Sist. Recur. For., Fuera de serie 3 (1994) 125-132.

[20] Koski V., Generative reproduction and genetic processes in nature, in: Giertych M., Mátyás Cs. (Eds.), Genetics of Scots pine, Elsevier, Amsterdam, 1991, pp. 59-73.

[21] Kuuluvainen T., Hokkanen T.J., Järvinen E., Pukkala T., Factors related to seedling growth in a boreal Scots pine stand: a spatial analysis of a vegetation-soil system, Can. J. For. Res. 23 (1993) 2101-2109.

[22] Lanner R.M., Seed dispersal in Pinus, in: Richardson D.M. (Ed.), Ecology and biogeography of Pinus, Cambridge University Press, Cambridge, 1998, pp. 281-295.

[23] Larson M.M., Schubert G.H., Root competition between Ponderosa pine seedlings and grass. USDA Forest Service, Rocky Mountain Forest and Range Experiment Station, RM-54, 1969.

[24] Leikola M., Kotisaari A., How to study natural regeneration, in: IUFRO Working Groups SI.01-2 and SI.05-08, Mountain Silviculture in the Southern Alps, 1989, pp. 1-5.

[25] Lust N., Analysis of a natural regeneration of Scots pine forest in the High Campine after a fire, Silva Gandavensis 53 (1988) 3-28.

[26] Matney T.G., Hodges J.D., Evaluating Regeneration Success, in: Duryea M.L, Dougherty P.M., (Eds.), Forest Regeneration Manual, Kluwer Academic Publishers, Dondrecht, 1991, pp. 321-331.

[27] Mátyás Cs., Seed Orchards, in: Giertych M., Mátyás Cs., (Eds.), Genetics of Scots pine, Elsevier, Amsterdam, 1991, pp. 125-147.

[28] Montero G., Generalities on silviculture of Pinus sylvestris L. in Spain, Invest. Agrar. Sist. Recur. For., Fuera de serie 3 (1994) 251-259.

[29] Oliver C.D., Larson B.C., Forest Stand Dynamics, John Wiley and Sons, New York, 1996.

[30] Porta J., López-Acevedo M., Roquero de Laburu C., Edafología para la agricultura y el medio ambiente, MundiPrensa, Madrid, 1994.

[31] Pukkala T., Simulation model for natural regeneration of Pinus sylvestris, Picea abies, Betula pendula and Betula pubescens, Silva Fennica 21 (1987) 37-53.

[32] Rawlings J.O., Applied regression analysis. A research tool, Wadsworth and Brooks/Cole, Belmont, 1988. 
[33] Rojo A., Montero G., Ortega C., Natural regeneration in Pinus sylvestris L., Invest. Agrar. Sist. Recur. For., Fuera de serie 3 (1994) 107-125.

[34] Ruha M., Hökkä H., Varmola M., Salminen H., Stability of height positions in young naturally regenerated stands of Scots pine, For. Ecol. Manage. 97 (1997) 155-163.

[35] Saksa T., Natural regeneration on prepared areas. Some reason for the variation, Invest. Agrar. Sist. Recur. For., Fuera de serie 3 (1994) 231-240.

[36] Sarvas R., Investigations on the flowering and seed crop of Pinus sylvestris, Commun. Inst. For. Fenn. 53 (1962) $1-198$.

[37] Schepper (De) C., Typology of the natural regeneration in a middle-aged Scots Pine Forest, Silva Gandavensis 53 (1988) 29-60.
[38] Steel R.G.D., Torrie J.H., Principles and procedures of statistics: a biometrical approach, McGraw-Hill, New York, 1980.

[39] Thompson J.D., Population differentiation in Mediterranean plants: insights into colonization history and the evolution and conservation of endemic species, Heredity 82 (1999) 229-236.

[40] Wagner R.G., Radosevich S.R., Interspecific competition and other factors influencing the perfomance of Douglasfir saplings in the Oregon Coast Range, Can. J. For. Res. 21 (1991) 829-835.

[41] Yazdani R., Lindgren D., Gene dispersion after natural regeneration under a widely-spaced seed-tree stand of Pinus sylvestris, Silvae Genet. 41 (1992) 1-5.

To access this journal online: www.edpsciences.org 